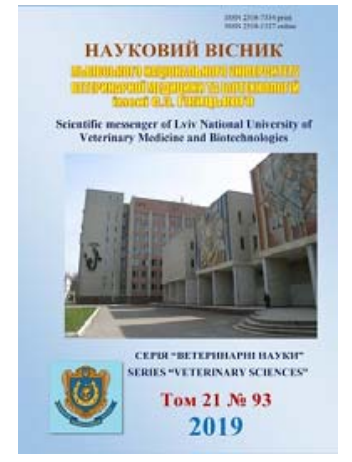

\section{Науковий вісник Дьвівського національного університету ветеринарної медицини та біотехнологій імені С.3. Гжицького. Серія: Ветеринарні науки \\ Scientific Messenger of Lviv National University of Veterinary Medicine and Biotechnologies. Series: Veterinary sciences}

ISSN 2518-7554 print ISSN 2518-1327 online doi: $10.32718 /$ nvlvet 9324

http://nvlvet.com.ua

UDC 636.4.087.7:615.322:612.015.3

\title{
The investigation of the influence which is done as a result of macleaya cordata and biologically active additives on the carbohydrate metabolism in pigs
}

\author{
I.O. Zhukova ${ }^{1}$, A.A. Molchanov ${ }^{1}$, I.O. Kostiuk ${ }^{1}$, O.M. Bobrytska ${ }^{1}$, N.I. Lonhus ${ }^{1}$, I.A. Ionov ${ }^{2}$ \\ ${ }^{1}$ Kharkiv State zooveterinary Academy, Kharkiv, Ukraine \\ ${ }^{2}$ Kharkiv National Pedagogical University named after G.S. Skovorody, Kharkiv, Ukraine
}

Article info

Received 11.02.2019

Received in revised form 13.03 .2019

Accepted 14.03.2019

Kharkiv state zooveterinary academy, Mala Danilivka, Dergachi district, Kharkiv region, 62341, Ukraine.

Tel.: +38-095-773-65-26

E-mail:patfiz@zoovet.kh.ua

Kharkiv National Pedagogical University named

after G.S. Skovorody,

Alchevskykh (Artema) Str., 29, Kharkiv, 61002, Ukraine.
Zhukova, I.O., Molchanov, A.A., Kostiuk, I.O., Bobrytska, O.M., Lonhus, N.I., \& Ionov, I.A. (2019). The investigation of the influence which is done as a result of macleaya cordata and biologically active additives on the carbohydrate metabolism in pigs. Scientific Messenger of Lviv National University of Veterinary Medicine and Biotechnologies. Series: Veterinary sciences, 21(93), 137142. doi: $10.32718 /$ nvlvet9324

Pork production plays a significant role in meat balance of Ukraine. High productivity of pigs is accompanied with increased intensity of metabolic processes and intense functional activity of all organs and systems, which requires additional support. To grow a healthy livestock, it is necessary to use preparations and biologically active forage plant additives that help a body to realize productive qualities, fight against various pathogens, but do not harm the animal body and are safe in the production of meat products for human nutrition. The influence of phytobiotic of the cardiac macleaya (Macleáya cordáta $R$. Br.) has been investigated separately and in combination with vegetable additives (buckwheat, ground onion and buckwheat husks) as a source of flavonoids on the physiological state and carbohydrate metabolism of pigs. It has been determined that application of only macleaya supplements to the 30 and 60 days of studies leads to an increase in the number of erythrocytes by $16.7 \%$ and $23.2 \%(P<0.05)$ and hemoglobin concentration by $30.7 \%$ and $37.9 \%(P<0.01)$, as well as activation of anaerobic glycolysis, as evidenced by a significant increase in glucose concentration by $96.4-48.0 \%(P<0.01)$, lactate by $71.4-55.2 \%,(P<0.01)$ and activity of lactate dehydrogenase at 18.6-29.4\% $(P<0.05)$ and reduction of pyruvate content by $34.0-13.4 \%$ $(P<0.01)$ and activity of alkaline phosphatase - by $66.2 \%$ and $76.8 \%(P<0.01)$ in the corresponding terms of research. While using macleaya with green buckwheat, buckwheat and onion husks, the hematological parameters and parameters of carbohydrate metabolism were at the level of the control group, confirming the significant decrease in the concentration of glucose and lactate compared with the control and shift ratio lactate / pyruvate towards pyruvate. This fact suggests that bioflavonoids, which are part of plant additives, have not only antioxidant properties, but also serve as a correction and stabilizer of carbohydrate metabolism and mitigate the side hypoxic effects of alkaloids of phytobiotic of the macleaya cordata.

Key words: macleaya cordata, erythrocytes, hemoglobin, carbohydrate metabolism, lactate, pyruvate, lactate dehydrogenase, ratio of lactate/pyruvate.

\section{Дослідження впливу маклеї серцевидної та біологічно активних добавок на вуглевод- ний обмін свиней}

\author{
I.О. Жукова ${ }^{1}$, А.А. Молчанов ${ }^{1}$, І.О. Костюк ${ }^{1}$, О.М. Бобрицька ${ }^{1}$, Н.І. Лонгус ${ }^{1}$, I.А. Іонов ${ }^{2}$ \\ ${ }^{1}$ Харківська державна зооветеринарна академія, м Харків, Україна \\ ${ }^{2}$ Харківський національний педагогічний університетет ім. Г.С. Сковороди, м. Харків, Украӥна
}

Виробництво свинини відіграє значну роль в м'ясному балансі України. Висока продуктивність свиней супроводжсуться підвищеною інтенсивністю процесів обміну речовин $і$ напруженою функціональною діяльністю всіх органів $і$ систем, щзо потребує додаткової підтримки. Для вирощування здорового поголів'я необхідно застосовувати препарати та біологічно активні кормові 
рослинні добавки, які допомагають організму реалізувати продуктивні якості, боротися з різними хвороботворними агентами, але не наносять шкоди самому організму тварини і є безпечними у виробництві м'ясної продукиї для харчування людини. Досліджено вплив фітобіотика маклеї серцевидної (Macleáya cordáta R. Br.) окремо і в комбінації з добавками рослинного походження (гречка посівна, мелене цибульне і гречане лушпиння) як джерело флавоноїдів на фізіологічний стан та вуглеводний обмін організму свиней. Встановлено, шо застосування у раціоні тільки добавки маклеї на 30 і 60 добу досліджень призводить до збільшення кількості еритроцитів на 16,7\% і 23,2\% (P < 0,05) і концентрації гемоглобіну на 30,7\% і 37,9\% (P< $<$,01) відповідно, а також активації анаеробного гліколізу, про щчо свідчть достовірне підвищення концентрації глюкози на 96,4-48,0\% (P < 0,01), лактату на 71,4-55,2\% (P<0,01) і активності лактатдегідрогенази на 18,6-29,4\% (P< 0,05) та зниження вмісту пірувату на 34,0-13,4\% $(P<0,01)$ і активності лужної фосфатази - на 66,2\% i 76,8\% (P<0,01) у відповідні терміни дослідження. За застосування разом з травою маклеї зеленої гречки, гречаного і циибльного лушпиння гематологічні показники $і$ вуглеводний обмін були на рівні показників контрольної групи, щзо підтверджує достовірним зниженням концентрації глюкози і лактату порівняно з контролем та зміщення коефіцієнту лактат/пірувату в бік пірувату. Цей факт свідчить про те, щчо біофлавоноїди, які входять до складу рослинних добавок, мають не тільки антиоксидантні властивості, а й слугують коректором і стабілізатором вуглеводного обміну $i$ пом'якшують побічний гіпоксичний вплив алкалоїдів фітобіотика маклеї сериевидної.

Ключові слова: маклея серцевидна, еритроцити, гемоглобін, лактат, піруват, лактатдегідрогеназа, коефіцієнт лакmam/nіруват.

\section{Вступ}

Виробництво свинини відіграє значну роль в м'ясному балансі України. Це одна із найбільш перспективних галузей, оскільки свині мають високий приріст живої маси молодняку, скоростиглість, короткий період поросності та багатоплідність. Висока продуктивність свиней супроводжується підвищеною інтенсивністю процесів обміну речовин і напруженою функціональною діяльністю всіх органів і систем, що потребує додаткової підтримки (Zhukova et al., 2016; Cherniy et al., 2018).

При роботі зі свинями необхідно враховувати те, що ці тварини дуже сприйнятливі до вірусних, бактеріальних та паразитарних захворювань, а також до різного виду стресів, в тому числі й до окисного (Gutyj et al., 2017; Iesina et al., 2018). Для вирощування здорового поголів'я у сучасних умовах ведення господарства необхідно, окрім вакцинування і регулярної дегельмінтизації, застосовувати препарати та біологічно активні кормові рослинні добавки, які допомагають організму боротися із різними патогенними агентами заразного або незаразного походження (Molchanov et al., 2016).

Одним із таких засобів $\epsilon$ маклея серцевидна (Macleáya cordáta $R$. Br.), рослина із роду Маклейя (Macleaya), сімейства Макові (Papaveraceae), яка $€$ природним антибіотиком (фітобіотиком). Осовними діючими речовинами маклеї $є$ ізохінолінові алкалоїди - сангвінарин і хелеритрин, вміст яких складає $0,7-$ 2\%. Застосовують iї для лікування уражень шкіри i слизових оболонок, інфікованих виразок і ран, що довго не загоюються. Маклея справляє протизапальну дію на слизову оболонку кишківника, шлунка, стравоходу i ротової порожнини, сприяє нормальному функціонуванню травної системи, підвищує засвоєння амінокислот та укріплює імунітет (Gudev et al., 2004; Chudak, 2008).

У наших попередніх дослідженнях на свинях в'єтнамської вислобрюхої породи доведено, що маклея має виражену прооксидантну дію i для пом'якшення цих іiі властивостей було застосовано необроблене зерно гречки посівної, у якій, згідно 3 літературними даними, вміщуються флавоноїди квер- цетин (до 8\%) і антоцианідини (Kovaliov et al., 1999; Molchanov, 2016; Zhukova et al., 2017).

Метою даної роботи є порівняльне дослідження впливу маклеї серцевидної та додавання до корму гречки посівної і меленого цибульного та гречкового лушпиння як джерела кверцетину і проантоцианідину на фізіологічний стан та вуглеводний обмін організму свиней в умовах промислового їх вирощування.

\section{Матеріал і методи досліджень}

Дослід було проведено на поросятах української білої породи, масою тіла 25-30 кг, віком 2,5 місяця, яких підбирали за принципом аналогів (тільки хрячки), що належать навчально-науково-практичному центру ХДЗВА. Тварини утримувались в окремих станках і були розподілені на 5 груп $(\mathrm{n}=5)$ - чотири піддослідні і одна контрольна. Годування проводили за стандартним раціоном, розробленим для цієї породи.

Поросята II групи одержували щоденно добавку меленої трави маклеї серцевидної у дозі 21 мг/кг корму (доза, яка не викликає ознак отруєння підібрана у попередніх дослідженнях) (Molchanov, 2016; Zhukova et al., 2017), III групи - 21 мг/кг корму і порошок необробленого зерна гречки як джерело кверцетину i проантоцианідину (“зелена гречка”) 3 розрахунку 6,25 г/кг маси тіла, IV групи - 21 мг/кг корму і мелений порошок цибульної лузки у дозі 10 г/кг маси тіла та V групі - запарену суміш меленої цибульної і гречкової лузки (1:1) у кількості 10 г/кг маси тіла. Змелене зерно і лушпиння згодовували індивідуально кожній тварині. Контрольній групі (I) маклею і добавки не задавали. Дози трави маклеї розраховували користуючись інструкцією із застосування препарату німецької компанії Phytobiotics "Sangrovit Extra", який вміщує 24-28\% трави маклеї.

Для досліджень у тварин відбирали кров до початку досліду та через 30 і 60 діб. У свиней визначали динаміку маси тіла, частоту серцевих скорочень i дихальнтх рухів, кількість еритроцитів за допомогою калібрувальних графіків (Zabolotskyi \& Poliakov, 1965), концентрацію гемоглобіну - гемоглобінцианідним методом (Kondrahin et al., 1985), кількість лейкоцитів підраховували у камері Горяєва. 
У сироватці крові визначали вміст глюкози в реакції 3 ортотолуїдиновим реактивом (Samohin et al., 1981; Kondrahin et al., 1985), піровиноградної кислоти модифікованим методом Умбрайта (Samohin et al., 1981), молочної кислоти - за методом Баркера і Саммерсона (Kolb \& Kamyshnikov, 1982) та активність ферментів лактатдегідрогенази (ЛДГ, КФ 1.1.1.27) i лужної фосфатази (ЛФ, КФ 3.1.3.1) з використанням наборів діагностикумів науково-виробничого підприємства “Філісіт Діагностика" (Україна) (Method to Define the Level of Activity...).
Результати досліджень оброблені статистично 3 використанням пакета програм Microsoft Excel 2003 (for Windows XP), вірогідність отриманих даних оцінювали за критерієм Ст'юдента.

\section{Результати та їх обговорення}

Впродовж досліду за поросятами вели клінічне спостереження, які показали, що різниці в поведінці, прийомі корму між дослідними і контрольними тваринами не помічали, однаковою була і їхня реакція на зовнішні подразники.

\section{Таблиця 1}

Динаміка маси тіла,частоти серцевих скорочень і дихання поросят протягом досліду $(\mathrm{M} \pm \mathrm{m} ; \mathrm{n}=5)$

\begin{tabular}{|c|c|c|c|c|}
\hline Група тварин & Строки досліджень, діб & $\begin{array}{l}\text { Мaca поросят, } \\
\text { кГ }\end{array}$ & $\begin{array}{c}\text { Частота } \\
\text { серцевих } \\
\text { скорочень }\end{array}$ & $\begin{array}{l}\text { Частота } \\
\text { дихання }\end{array}$ \\
\hline \multirow{3}{*}{ I - “контроль” } & До початку досліджень & $20,2 \pm 0,5$ & $108,2 \pm 2,5$ & $33,4 \pm 0,5$ \\
\hline & 30 & $31,2 \pm 0,7$ & $100,5 \pm 2,0$ & $31,3 \pm 0,8$ \\
\hline & 60 & $39,3 \pm 0,4$ & $99,0 \pm 1,3$ & $28,5 \pm 1,0$ \\
\hline \multirow{3}{*}{$\begin{array}{l}\text { II - добавка маклеї серцевидної, } 21 \text { мг/кг } \\
\text { корму }\end{array}$} & До початку досліджень & $21,7 \pm 1,1$ & $110,4 \pm 1,7$ & $35,2 \pm 0,5$ \\
\hline & 30 & $33,8 \pm 0,6$ & $90,1 \pm 1,4$ & $33,3 \pm 0,8$ \\
\hline & 60 & $40,4 \pm 0,6$ & $87,9 \pm 1,2 *$ & $24,5 \pm 1,0^{*}$ \\
\hline \multirow{3}{*}{$\begin{array}{l}\text { III - добавка маклеї серцевидної, } 21 \text { мг/кг + } \\
\text { “зелена гречка” } 3 \text { розрахунку } 6,25 \text { г/кг маси } \\
\text { тіла }\end{array}$} & До початку досліджень & $21,3 \pm 0,4$ & $110,4 \pm 1,7$ & $32,8 \pm 0,4$ \\
\hline & 30 & $34,2 \pm 1,2$ & $103,3 \pm 1,4$ & $30,1 \pm 0,5$ \\
\hline & 60 & $42,2 \pm 1,3$ & $100,7 \pm 1,2$ & $25,6 \pm 1,1$ \\
\hline \multirow{3}{*}{$\begin{array}{l}\text { IV - добавка маклеї серцевидної } 21 \text { мг/кг } \\
\text { корму + мелений порошок цибульного луш- } \\
\text { пиння у дозі } 10 \text { г/кг маси тіла }\end{array}$} & До початку досліджень & $20,8 \pm 1,7$ & $109,8 \pm 1,7$ & $31,6 \pm 0,9$ \\
\hline & 30 & $32,8 \pm 0,9$ & $100,6 \pm 1,4$ & $29,2 \pm 1,1$ \\
\hline & 60 & $44,6 \pm 1,2 *$ & $98,2 \pm 1,2$ & $26,3 \pm 1,5$ \\
\hline \multirow{3}{*}{$\begin{array}{l}\mathrm{V} \text { - добавка маклеї серцевидної } 21 \text { мг/кг } \\
\text { корму + суміш меленої цибульної і гречано- } \\
\text { го лушпиння }(1: 1) \text { кількості } 10 \text { г/кг маси тіла. }\end{array}$} & До початку досліджень & $22,4 \pm 1,2$ & $103,3 \pm 0,9$ & $30,8 \pm 0,8$ \\
\hline & 30 & $33,9 \pm 0,5$ & $102,6 \pm 1,5$ & $29,9 \pm 1,3$ \\
\hline & 60 & $45,2 \pm 1,5^{*}$ & $98,7 \pm 0,9$ & $27,7 \pm 1,4$ \\
\hline
\end{tabular}

Примітка: $*$ - різниця значень вірогідна за $(\mathrm{P} \leq 0,05)$, стосовно значень такого показника у контролі у відповідний термін досліджень (І група)

Дослідження показали, що при надходженні малих доз маклеї серцевидної маса поросят у II, III IV i V піддослідних групах перевищувала контроль на 30 добу на $8,3-9,6-5,1-8,6 \%$ і на 60 добу - на 2,8-7,3$13,5-18,0 \%,(\mathrm{P} \leq 0,05)$ відповідно (табл. 1). Динаміка частота серцевих скорочень і дихання відповідала віковим особливостям свиней, а стосовно до контролю відмічались незначне зниження ЧСС на 11,5\% і ЧД - на $12,6 \%(\mathrm{P} \leq 0,05)$ тільки у групі, яка одержуала тільки траву маклеї (II).

Аналіз гематологічних показників показав вікове зростання в усіх групах кількості еритроцитів, лейкоцитів і концентрації гемоглобіну (табл. 2). За додавання до корму тільки маклеї серцевидної у дозі 21 мг/кг корму (II група) виявлено підвищення на 30 i 60 добу досліду вмісту еритроцитів на 16,7\% і 23,2\% $(\mathrm{P}<0,05)$ і гемоглобіну - на $30,7 \%$ і $37,9 \%(\mathrm{P}<0,01)$ відповідно стосовно до контролю. У III, IV i V групах також відмічалось збільшення цих показників: еритроцитів у середньому на 19,5 і $21,2 \%$ і гемоглобіну на 31,6 і 37,1\% відповідно на 30 і 60 добу досліджень. Вірогідно такі зміни є показником підвищення продуктивних можливостей, які розвиваються внаслідок тривалого надходження трави до організму поросят. Дані таблиці 2 показують, що за додавання до корму як однієї маклеї, так і у поєднанні з біодобавками кількість лейкоцитів в крові свиней не змінювалась, тобто усі досліджувані препарати на цей показник не впливали.

Зміни біохімічних показників сироватки крові під впливом фітопрепаратів були більш показовими (табл. 3). На 30 і 60 добу від початку експерименту у II дослідній групі поросят виявлено достовірне зростання концентрації глюкози відповідно на 96,4-48,0\% $(\mathrm{P}<0,01)$, лактату - на 71,4-55,2\%, $(\mathrm{P}<0,01)$ і зниження вмісту пірувату на $18,6-29,4 \%(\mathrm{P}<0,05)$. Коефіцієнт лактат/піруват у цій групі зміщено у бік молочної кислоти, що свідчить про стимуляцію вуглеводного обміну в організмі піддослідних поросят і активацію анаеробного гліколізу.

У III, IV i V групах, які додатково до маклеї серцевидної отримували біологічно активні добавки, рівень глюкози лактату і пірувату майже не відрізнявся від контролю, а коефіцієнт лактат/піруват зміщувався у бік піровиноградної кислоти, що є ознакою активації аеробного окиснення вуглеводів і фосфорилювання. 


\section{Таблиця 2}

Кількість еритроцитів, лейкоцитів та вміст гемоглобіну в крові поросят протягом тривалого досліду $(\mathrm{M} \pm \mathrm{m} ; \mathrm{n}=5)$

\begin{tabular}{|c|c|c|c|c|}
\hline \multirow{2}{*}{ Показники } & \multirow{2}{*}{ Групи тварин } & \multicolumn{3}{|c|}{ Термін досліджень } \\
\hline & & до початку досліду & 30 діб & 60 діб \\
\hline \multirow{5}{*}{$\begin{array}{l}\text { Еритроцити, Т/дм }{ }^{3} \\
\text { (фізіологічна норма } \\
5,5-6,5)\end{array}$} & I & $6,02 \pm 0,11$ & $6,11 \pm 0,03$ & $6,22 \pm 0,02$ \\
\hline & II & $6,51 \pm 0,13$ & $7,13 \pm 0,05^{*}$ & $7,66 \pm 0,08^{*}$ \\
\hline & III & $6,16 \pm 0,02$ & $7,35 \pm 0,13$ & $7,52 \pm 0,04$ \\
\hline & IV & $6,11 \pm 0,05$ & $7,24 \pm 0,05$ & $7,36 \pm 0,08$ \\
\hline & $\mathrm{V}$ & $6,16 \pm 0,07$ & $7,31 \pm 0,07$ & $7,73 \pm 0,04$ \\
\hline \multirow{5}{*}{$\begin{array}{l}\text { Гемоглобін, г/дм } \\
\text { (норма 90-130) }\end{array}$} & I & $7,22 \pm 0,10$ & $7,88 \pm 0,03$ & $7,94 \pm 0,02$ \\
\hline & II & $7,50 \pm 0,52$ & $10,30 \pm 0,20 * *$ & $10,95 \pm 0,17^{* *}$ \\
\hline & III & $7,40 \pm 0,03$ & $9,90 \pm 0,17$ & $10,77 \pm 0,16$ \\
\hline & IV & $7,51 \pm 0,52$ & $10,39 \pm 0,52$ & $11,22 \pm 0,12$ \\
\hline & V & $7,40 \pm 0,03$ & $10,82 \pm 0,13$ & $10,67 \pm 0,08$ \\
\hline \multirow{5}{*}{$\begin{array}{l}\text { Лейкоцити, Г/дм³ } \\
\text { (норма 9-12) }\end{array}$} & I & $12,40 \pm 0,33$ & $14,12 \pm 0,15$ & $16,10 \pm 0,37$ \\
\hline & II & $11,70 \pm 0,27$ & $13,87 \pm 0,33$ & $15,22 \pm 0,14$ \\
\hline & III & $11,60 \pm 0,07$ & $14,86 \pm 0,18$ & $15,65 \pm 0,33$ \\
\hline & IV & $13,40 \pm 0,09$ & $14,73 \pm 0,33$ & $14,95 \pm 0,24$ \\
\hline & $\mathrm{V}$ & $12,63 \pm 0,23$ & $14,12 \pm 0,16$ & $15,28 \pm 0,36$ \\
\hline
\end{tabular}

Примітка: * - різниця значень вірогідна за $\mathrm{P}<0,05 ; * *-\mathrm{P}<0,01$, відносно показника контролю у відповідний термін досліджень (І група)

\section{Таблиця 3}

Концентрація глюкози, лактата і пірувата в крові свиней після тривалого щоденного згодовування маклеї серцевидної і біологічно активних кормових добавок $(\mathrm{M} \pm \mathrm{m} ; \mathrm{n}=5)$

\begin{tabular}{|c|c|c|c|c|}
\hline \multirow{2}{*}{ Показники } & \multirow{2}{*}{ Групи тварин } & \multicolumn{3}{|c|}{ Термін досліджень } \\
\hline & & до початку досліду & 30 діб & 60 діб \\
\hline \multirow{5}{*}{$\begin{array}{l}\text { Глюкоза, } \\
\text { ммоль/дм }\end{array}$} & I & $4,00 \pm 0,13$ & $3,82 \pm 0,10$ & $3,77 \pm 0,02$ \\
\hline & II & $4,11 \pm 0,20$ & $5,54 \pm 0,04 * *$ & $5,58 \pm 0,12 * *$ \\
\hline & III & $4,26 \pm 0,12$ & $3,18 \pm 0,02$ & $3,30 \pm 0,10$ \\
\hline & IV & $4,32 \pm 0,15$ & $3,52 \pm 0,04$ & $3,52 \pm 0,04$ \\
\hline & $\mathrm{V}$ & $4,36 \pm 0,14$ & $3,18 \pm 0,02$ & $4,10 \pm 0,05$ \\
\hline \multirow{5}{*}{$\begin{array}{l}\text { Лактат, } \\
\text { ммоль/дм }\end{array}$} & I & $0,31 \pm 0,03$ & $0,28 \pm 0,05$ & $0,29 \pm 0,03$ \\
\hline & II & $0,32 \pm 0,02$ & $0,48 \pm 0,03 * *$ & $0,45 \pm 0,01 * *$ \\
\hline & III & $0,29 \pm 0,03$ & $0,27 \pm 0,03$ & $0,26 \pm 0,03$ \\
\hline & IV & $0,28 \pm 0,02$ & $0,24 \pm 0,03$ & $0,27 \pm 0,03$ \\
\hline & $\mathrm{V}$ & $0,31 \pm 0,03$ & $0,23 \pm 0,03$ & $0,28 \pm 0,03$ \\
\hline \multirow{5}{*}{$\begin{array}{l}\text { Піруват, } \\
\text { мкмоль/дм }\end{array}$} & I & $312,7 \pm 11,2$ & $326,2 \pm 10,3$ & $310,2 \pm 6,3$ \\
\hline & II & $333,3 \pm 10,0$ & $275,0 \pm 19,2 *$ & $239,7 \pm 9,6^{* *}$ \\
\hline & III & $315,8 \pm 20,6$ & $285,1 \pm 15,9$ & $274,9 \pm 11,6$ \\
\hline & IV & $332,1 \pm 19,8$ & $225,0 \pm 39,2$ & $275,0 \pm 39,2$ \\
\hline & $\mathrm{V}$ & $310,8 \pm 20,6$ & $285,1 \pm 15,9$ & $299,1 \pm 15,9$ \\
\hline \multirow{5}{*}{$\begin{array}{l}\text { Коефіціснт } \\
\text { лактат/піруват }\end{array}$} & I & $0,99 \pm 0,01$ & $0,85 \pm 0,02$ & $0,93 \pm 0,02$ \\
\hline & II & $0,96 \pm 0,06$ & $1,75 \pm 0,01$ & $1,88 \pm 0,01$ \\
\hline & III & $0,92 \pm 0,02$ & $0,95 \pm 0,02$ & $0,94 \pm 0,03$ \\
\hline & IV & $0,84 \pm 0,06$ & $1,07 \pm 0,02$ & $0,98 \pm 0,01$ \\
\hline & $\mathrm{V}$ & $1,00 \pm 0,02$ & $0,81 \pm 0,01$ & $0,94 \pm 0,03$ \\
\hline
\end{tabular}

Примітка: * - різниця значень вірогідна за $\mathrm{P}<0,05 ; * *-\mathrm{P}<0,01$, відносно показника контролю у відповідний термін досліджень (І група)

Активність ЛДГ в сироватці крові у II дослідній групі поросят під впливом маклеї серцевидної підвищувалася через 30 діб - на $34,0 \%$ і на 60 добу - на $13,4 \%(\mathrm{P}<0,01)$, а активність лужної фосфатази, навпаки, знижувалась у відповідні терміни дослідження на $66,2 \%$ і $76,8 \%(\mathrm{P}<0,01)$ (табл. 4). Між змінами активності лактатдегідрогенази і лужної фосфатази в сироватці крові цієї групи поросят простежується прямий зв'язок, що свідчить про посилення витрачання фосфору і переважання гліколізу над фосфорилюванням.

У III, IV i V групах активність ферментів ЛДГ і ЛФ майже не відрізнялись від показників у контрольних групах. 


\section{Таблиця 4}

Активність лактатдегідрогенази та лужної фосфатази сироватки крові свиней при тривалому щоденному згодовуванні маклеї серцевидної та біологічно активних добавок $(\mathrm{M} \pm \mathrm{m} ; \mathrm{n}=5)$

\begin{tabular}{lcccc}
\hline \multirow{2}{*}{ Показники } & \multirow{2}{*}{ Групи тварин } & \multicolumn{3}{c}{ Термін досліджень } \\
\cline { 3 - 5 } & I & до початку досліду & 30 діб & 60 діб \\
\hline \multirow{2}{*}{ ЛДГ } & II & $23,94 \pm 0,8$ & $22,33 \pm 0,3$ & $24,0 \pm 1,0$ \\
ммоль $/$ год.•дм ${ }^{3}$ & III & $22,3 \pm 1,2$ & $29,93 \pm 0,7^{*}$ & $27,22 \pm 1,6^{*}$ \\
& IV & $24,22 \pm 1,1$ & $20,56 \pm 1,2$ & $20,1 \pm 1,8$ \\
& V & $21,77 \pm 0,9$ & $24,12 \pm 1,2$ & $23,2 \pm 0,7$ \\
\multirow{2}{*}{ ЛФ, } & I & $172,0 \pm 13,8$ & $23,37 \pm 1,7$ & $145,0 \pm 12,1$ \\
мкмоль/год.•дм & II & $181,0 \pm 15,2$ & $166,0 \pm 9,9$ & $82,0 \pm 0,5^{*}$ \\
& III & $196,0 \pm 16,7$ & $99,9 \pm 9,0^{*}$ & $155,5 \pm 17,3$ \\
& IV & $166,1 \pm 10,1$ & $159,5 \pm 24,1$ & $142,3 \pm 9,5$ \\
\end{tabular}

Примітка: * - P < 0,01, стосовно показника контролю у відповідний термін досліджень (І група)

\section{Висновки}

Таким чином, щоденне тривале згодовування свиням добавки меленої трави маклеї серцевидної у дозі 21 мг/кг корму призводить до інтенсифікації вуглеводного обміну, про що свідчить активація анаеробного гліколізу (підвищення концентрації глюкози, лактату і активності ЛДГ), а додаткове введення у раціон порошку необробленого зерна гречки 3 розрахунку 6,25 г/кг маси тіла, меленого цибульного окремо та суміші цибульного і гречкового лушпиння у кількості 10 г/кг маси тіла призводить до нормалізації гематологічних показників і вуглеводного обміну, про що свідчить достовірне зниження концентрації глюкози і лактату та зміщення коефіціенту лактат/пірувату у бік пірувату. Цей факт підтерджує, що біофлавоноїди, які входять до складу рослинних добавок, мають не тільки антиоксидантні властивості (Zhukova et al., 2017), а й слугують корректором і стабілізатором вуглеводного обміну.

\section{References}

Chudak, R.A. (2008). Theoretical and Experimental Justification of Phytobiotics Usage in the Process of Livestock Feeding. [dissertation]. Kyiv: National Agricultural University (in Ukrainian).

Cherniy, N.V., Matsenko, E.V., Shchepetilnikov, Yu.A., Maslak, Yu.V., Machula, O.S., Furda, I.V., Voronyak, V.V., \& Gutyj, B.V. (2018). Influence of the supplement "Press-Acid" on proteinmineral metabolism and resistance of piglets. Scientific Messenger of Lviv National University of Veterinary Medicine and Biotechnologies, 20(83), 320-324. doi: $10.15421 /$ nvlvet8364.

Gudev, D., Popova-Ralcheva, S., Moneva, P., Bonovska, M., Valchev, G., Valcheva, A. (2004). Effect of supplemental Sangrovit on some biochemical indices and leukocytes phagocytic activity in growing pigs. Archiva Zootechnica, Sofia, Bulgaria, 7, 19-26. https://www.ibna.ro/arhiva/AZ\%207/AZ\%207_03_Gu dev.pdf.
Gutyj, B., Leskiv, K., Shcherbatyy, A., Pritsak, V., Fedorovych, V., Fedorovych, O., Rusyn, V., \& Kolomiiets, I. (2017). The influence of Metisevit on biochemical and morphological indicators of blood of piglets under nitrate loading. Regulatory Mechanisms in Biosystems, 8(3), 427-432. doi: 10.15421/021766.

Iesina, E.V., Tishkina, N.M., \& Gutyj, B.V. (2018). Pathoanatomical diagnosis, treatment and preventive measures at pigs gastroenterocolitis. Scientific Messenger of Lviv National University of Veterinary Medicine and Biotechnologies, 20(83), 429-434. doi: $10.15421 /$ nvlvet8384.

Ioku, K., Tsushida, T., Takei, Y., Nakatani, N., \& Terao, J. (1995). Antioxidative activity of quercetin and quercetin monoglucosides in solution and phospholipid bilayers. Biochimica and Biophysica Acta, 1234(1), 99104. https://www.ncbi.nlm.nih.gov/pubmed/7880864.

Kolb, V.H., \& Kamyshnikov, V.S. (1982). Manual on Clinical Chemistry. Minsk: Belarus (in Russian).

Kondrahin, I.P., Kurylov, N.V., Malahov, A.H. et al. (1985), Clinical Lab Diagnostics in Veterinary: Comprehensive Manual. Moscow: Agropromizdat, 143145 (in Russian).

Kovaliov, V.B., Kovchan, V.V., \& Kolchyna, O.Y. (1999). Mechanism of a Treating Activity of Bioflavonoid Quercetin. Ukrainian Medical Almanac, 2(4), 176-184 (in Ukrainian).

Method to Define the Level of Activity of Alkaline Phosphatase in Blood and Tissues Serum. "Filicit Diagnostics" (in Ukrainian).

Molchanov, A.A. (2016). The Dynamics of Hematological and Biochemical Indicators in the Pigs' Blood under the Influence of Biologically Active Substances with Plant-Based Origin. Problems of Zoo Engineering and Veterinary Medicine, 2(33), 82-86 (in Ukrainian).

Molchanov, A.A., Zhukova, I.O., \& Antipin, S.L. (2016). Justification of Phytobiotics Usage to Correct Defensive Functions of Pigs' Organism. Scientific Messenger of LNU of Veterinary Medicine and Biotechnologies, 18(65), 76-81. https://nvlvet.com.ua/index.php/ agriculture/article/view/3504 (in Ukrainian). 
Samohin, V.T., Petrov, V.E., Kondryhyn, V.Y. et al. (1981). Guidelines to Apply the Unified Biochemical Methods to Examine Blood, Urine and Milk in Veterinary Labs. Moscow : VASKhNIL, 26 (in Russian).

Zabolotskyi, V.T., \& Poliakov, V.F. (1965). Methodology of Counting of Red Blood Cells by Colorimeter FEKM. Soviet Union Institute of Experimental Veterinary, 31, 281-286.

Zhukova, I.O., Kostiuk, I.O., Bazdyrieva, N.O., Sobakar, A.B., \& Kochevenko, O.S. (2016). Experience and Prospect of the Usage of Macleaya Cordata and Mac- leaya Microcarpa in Animal Husbandry. Problems of Zoo Engineering and Veterinary Medicine, 2(33), 8286 (in Ukrainian).

Zhukova, I.O., Molchanov, A.A., \& Antipin, S.L. (2017). The Increase of Pigs' Organism Resistance to Oxidational Stress by the Plant-Based means. Scientific Messenger of LNU of Veterinary Medicine and Biotechnologies, 19(74), 33-37. doi: 10.15421/nvlvet7408 (in Ukrainian). 